\title{
Phenolic and Flavonoid Compounds in Aqueous Extracts of Thunbergia laurifolia Leaves and Their Effect on the Toxicity of the Carbamate Insecticide Methomyl to Murine Macrophage Cells
}

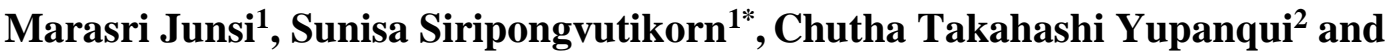 Worapong Usawakesmanee ${ }^{1}$}

${ }^{1}$ Department of Food Technology, Faculty of Agro-Industry, Prince of Songkla University, HatYai, Songkhla 90112, Thailand; ${ }^{2}$ Interdisciplinary Graduate School of Nutraceutical and Functional Food, Prince of Songkla University, Hat-Yai, Songkhla 90112, Thailand

*Corresponding author. Sunisa Siripongvutikorn, Assistant Professor, Department of Food Technology, Faculty of Agro-Industry Prince of Songkla University, Hat-Yai, Songkhla, Thailand

Submission Date: February $23^{\text {rd }}, 2017$, Acceptance Date: July $21^{\text {st }}, 2017$, Publication Date: July $31^{\text {st }}, 2017$

Citation: Junsi M., Siripongvutikorn S., Yupanqui C.T., Usawakesmanee W.: Phenolic and Flavonoid Compounds in Aqueous Extracts of Thunbergia laurifolia Leaves and Their Effect on the Toxicity of the Carbamate Insecticide Methomyl to Murine Macrophage Cells. Functional Foods in Health and Disease 2017; 7(7): 529-544. https://doi.org/10.31989/ffhd.v7i7.336

\begin{abstract}
Background: Thunbergia laurifolia is a Thai herb and has been used in Thai folklore medicine for centuries. Generally, Thais consume T. laurifolia as a herbal tea because of its beneficial properties as an antidote for chemical toxins, drug-, arsenic-, strychnine-, alcohol- and foodpoisoning. However, its effectively against some insecticide compounds, e.g. methomyl, has not yet been determined.
\end{abstract}

Objective: To examine the protective effect of aqueous extract from leaves of $T$. laurifolia on methomyl (MT) poisoning of murine macrophage cells (anti-MT effect) and to identify phenolic and flavonoid compounds in the extract.

Methods: T. laurifolia was extracted with water and stored in freeze-dried form. The extract was investigated for its antioxidant activity and some phenolic and flavonoid compounds were identified using liquid chromatography-mass spectrometry (LC-MS). To study anti-MT effects in RAW264.7 murine macrophage cells, these were treated with leaf extract either before (pretreatment), concomitantly (combined) or after (post-treatment) exposure to MT and cell viability determined in an MTT test (3-(4,5-dimethylthiazol-2-yl)-2,5-diphenyltetrazolium bromide). 
Results: The extract exhibited strong antioxidant properties based on total extractable phenolic content (TPC), total extractable flavonoid content (TFC), 2,2'-azino-bis(3-ethylbenzothiazoline-6sulphonic acid) (ABTS) radical scavenging, 2,2-diphenyl-1-picrylhydrazyl (DPPH) radical scavenging and Ferric ion reducing antioxidant power (FRAP) activity. The LC-MS analyses of phenolic compounds indicated the presence of caffeic acid, rosmarinic acid, catechin, rutin, isoquercetin, quercetin and apigenin as bioactive compounds. Viability of RAW 264.7 murine macrophage cells treated with MT was increased significantly by post-treatment with leaf extract but not by combined or pre-treatments.

Conclusion: The aqueous extract of $T$. laurifolia leaves contained abundant antioxidant activity. Flavonoids present were catechin, rutin, isoquercetin, quercetin and apigenin. The aqueous leaf extract was able to help cells recover from the effects of exposure to MT.

Keywords: Thunbergia laurifolia, phenolics, flavonoids, methomyl, RAW264.7 murine macrophages, insecticide

\section{INTRODUCTION}

The rapid increase of insecticide usage is an important concern for Thailand and other developing countries with an intensive agriculture [1]. Agriculture in Thailand is reported to be heavily dependent up on pesticide usage for crop protection in order to increase production levels, quality and appearance [2]. Humans are at the top of the food chain, therefore, food containing toxic contaminants will potentially accumulate in the human body [3]. Methomyl, a carbamate insecticide, is a very toxic and hazardous insecticide [4] which is used in various crops in Thailand. Its toxic action relates to acetyl cholinesterase inhibition, which includes important enzymes of the human nervous systems [5]. Based on Thai folk medicine, Thunbergia laurifolia, can be used to reduce the toxicity of insecticides.

T. laurifolia, which has the Thai name 'Rang Jued', belongs to the family Acanthaceae, [6] and has been used in Thai traditional medicine for many centuries. The extracts of fresh and dried leaves, barks and roots are mainly used as an antidote for treating insecticide-, drug-, arsenic-, strychnine-, alcohol-, and food poisoning and the effects of chemical toxins [7,8,9,10,11]. Moreover, this plant has been reported to have antioxidant and anti-inflammatory properties $[12,13]$. However, recently The Thai Food and Drug Administration (Thai FDA) announced a ban on producing $T$. laurifolia for food or drinking products because of a lack of scientific data about its safety $[14,15]$. Our previous studies demonstrated that the aqueous leaf extract of $T$. laurifolia can reduce nitric oxide production and provide a protective effect on RAW 264.7 macrophage cells treated with cadmium (Cd) and chlorpyrifos (CP) toxin. Moreover, high performance liquid chromatography (HPLC) showed that the leaf extract contained the phenolics pyrogallol, caffeic acid, rosmarinic acid and rutin compounds.

The objectives of this study were to determine the effect of $T$. laurifolia aqueous extract on protecting murine macrophages -against MT insecticide, which is the most commonly used insecticide in fresh produce, and to characterize more comprehensively the phenolic content of the leaf extract by LC-MS. 


\section{MATERIALS AND METHODS}

\section{Chemicals and cell culture media}

Chemicals used for determination of cells culture were purchased from Gibco (Carlsbad, California). Most of the chemicals used for the determination of antioxidant activity and LC-MS analysis were purchased from Sigma-Aldrich, Seelze, Germany otherwise from Merck, Darmstadt, Germany; Ajax Finechem, Auckland, New Zealand; QRAC, Selangor, Malaysia; Fisher Scientific, Leicestershire, England; and LAB-SCAN, Dublin, Ireland.

\section{Plant material}

Developing or intermediate stage leaves of $T$. laurifolia, which can still be folded without breaking easily, were purchased directly from the contact farmer in Bangkok, Thailand and transported to laboratory within $24 \mathrm{~h}$ of harvesting.

\section{Plant preparation and extraction}

Following a traditional folk medicine method, leaves were washed with tap water, drained and air dried for 5-8 d to obtain a moisture content of 8-10\% (w/w), ground to be a fine powder with 2040 mesh, and stored in a dark bottle at room temperature before being used within 6 months. The powdered leaves were extracted in hot water at $98 \pm 1^{\circ} \mathrm{C}(1: 10 \mathrm{w} / \mathrm{v})$ for $1 \mathrm{~h}$, and then filtered through three layers of gauze followed by Whatman No. 4 filter paper. The filtrate was freeze-dried and stored in a desiccator at $4{ }^{\circ} \mathrm{C}$ for further study as crude, dried extract (CDE) [16].

\section{Determination of total extractable phenolic content}

TPC of the CDE was determined by using the Folin-Ciocalteu assay modified from Tan and Kassim [17]. Briefly, $500 \mu \mathrm{l}$ of $1 \mathrm{mg} / \mathrm{ml}$ of CDE was added to tube. Then, $2.5 \mathrm{ml}$ of Folin-Ciocalteu reagent $(10 \% \mathrm{v} / \mathrm{v})$ and $2.0 \mathrm{ml}$ of sodium carbonate $(7.5 \% \mathrm{w} / \mathrm{v})$ were added and mixed thoroughly. After incubation for $30 \mathrm{~min}$ in the dark at ambient temperature, the absorbance was measured at $765 \mathrm{~nm}$ using a spectrophotometer. The measured values were compared with a standard curve prepared with gallic acid and expressed as micromole of gallic acid equivalents/g CDE (GAE/g CDE).

\section{Determination of total extractable flavonoid content}

Total extractable flavonoid compounds were determined by the aluminum chloride colorimetric method [18]. Briefly, the test sample of $150 \mu \mathrm{l}$ ethanolic CDE solution was mixed with $2 \%$ w/v $\mathrm{AlCl}_{3}$ in 96-well plates. After 15 min of incubation in the dark at room temperature, the absorbance was measured at $435 \mathrm{~nm}$ by spectrophotometric microplate reader. The measured values were compared with a standard curve prepared with quercetin and expressed as micromole of quercetin equivalents/g CDE (QE/g CDE).

\section{Determination of antioxidant activity}

2,2'-azino-bis(3-ethylbenzothiazoline-6-sulphonic acid (ABTS) radical scavenging: The ABTS assay was performed after the modified method of Arnao et al. [19]. The stock solutions included $7.4 \mathrm{mM}$ ABTS solution and $2.6 \mathrm{mM}$ potassium persulphate solution. The working solution was prepared by mixing the two stock solutions in equal quantities and allowing them to 
react for 12-14 $\mathrm{h}$ at room temperature in the dark. The solution was then diluted by mixing $1 \mathrm{ml}$ of this solution with $48 \mathrm{ml}$ of distilled water in order to obtain an absorbance of $1.1 \pm 0.02$ units at $734 \mathrm{~nm}$ using a spectrophotometer. ABTS solution was prepared freshly and used within $2 \mathrm{~h}$. The prepared CDE $(150 \mu \mathrm{l})$ was mixed with $2.85 \mathrm{ml}$ of ABTS solution and the mixture was kept at room temperature for $2 \mathrm{~h}$ in the dark. The measured values were compared with a standard curve prepared with Trolox and expressed as $\mu$ mole of Trolox equivalents/g CDE (TE/g CDE).

2,2-diphenyl-1-picrylhydrazyl (DPPH) radical scavenging activity: DPPH assay was performed after the modified method of Shimada et al. [20]. Briefly, $1.5 \mathrm{ml}$ of the extract was added to $1.5 \mathrm{ml}$ of $0.2 \mathrm{mM}$ DPPH in $95 \%$ ethanol. The mixture was shaken lightly and incubated at ambient temperature for $30 \mathrm{~min}$ in the dark. The absorbance was determined at $517 \mathrm{~nm}$ using a spectrophotometer. The measured values were compared with a standard curve prepared with Trolox and expressed as $\mu$ mole of Trolox equivalents/g CDE (TE/g CDE).

Ferric ion reducing antioxidant power (FRAP) activity: FRAP assay was performed after the modified method of Benzie and Strain [21]. The stock solutions included $300 \mathrm{mM}$ acetate buffer [pH 3.6, 3.1 g sodium acetate trihydrate $\left(\mathrm{C}_{2} \mathrm{H}_{3} \mathrm{NaO}_{2} .3 \mathrm{H}_{2} \mathrm{O}\right)$ and $16 \mathrm{ml}$ acetic acid $\left.\left(\mathrm{C}_{2} \mathrm{H}_{4} \mathrm{O}_{2}\right)\right]$, $10 \mathrm{mM} \mathrm{2,} \mathrm{4,} \mathrm{6-} \mathrm{tripyridyl-s-triazine} \mathrm{(TPTZ)} \mathrm{solution} \mathrm{in} 40 \mathrm{mM} \mathrm{HCl}$, and $20 \mathrm{mM}$ of Iron(III) chloride hexahydrate $\left(\mathrm{FeCl}_{3} \cdot 6 \mathrm{H}_{2} \mathrm{O}\right)$ solution. The fresh working solution was prepared by mixing $25 \mathrm{ml}$ acetate buffer, $2.5 \mathrm{ml} \mathrm{TPTZ}$ solution, and $2.5 \mathrm{ml} \mathrm{FeCl} 3.6 \mathrm{H}_{2} \mathrm{O}$ solution and then warmed to $37^{\circ} \mathrm{C}$ before use. The CDE at $0.1 \mathrm{mg} / \mathrm{ml}(150 \mu \mathrm{l})$ was allowed to react with $2.85 \mathrm{ml}$ of the FRAP solution for $30 \mathrm{~min}$ in the dark. Readings of the colored product (ferrous tripyridyltriazine complex) were then performed at $593 \mathrm{~nm}$. The measured values were compared with a standard curve prepared with Trolox and expressed as $\mu$ mole of Trolox equivalents/g CDE (TE/g CDE).

Ferrous ion chelating activity (FIC): The ferrous ion chelating assay was performed after the method of Decker and Welch [22] with modifications. One milliliter of extract solution was mixed with $3.7 \mathrm{ml}$ of distilled water. The mixture was then reacted with $0.1 \mathrm{ml}$ of $2 \mathrm{mM}$ iron (II) chloride $\left(\mathrm{FeCl}_{2}\right)$ and $0.2 \mathrm{ml}$ of $5 \mathrm{mM}$ ferrozine for $20 \mathrm{~min}$ at ambient temperature. The absorbance was read at $562 \mathrm{~nm}$ using a spectrophotometer. The control was prepared in the same manner except that distilled water was used instead of the sample. A standard curve was prepared using ethylenediaminetetraacetic acid (EDTA). The activity was expressed as $\mu$ mole EDTA equivalent (EDTAE)/g CDE.

\section{Determination of phenolic and flavonoid compounds by LC-MS}

CDE was dissolved with water $(50 \mathrm{mg} / \mathrm{ml})$ before subjected to quantitatively measure by LC-MS according to the methodology and equipment of the Central Laboratory (Bangkok, Thailand) Co., Ltd. LC-MS analysis was performed using an Agilent 1100 series liquid chromatograph/mass selective detector equipped with a quadrupole mass spectrometer (Agilent Technologies, Waldrom, Germany). The liquid chromatographic system consisted of a quaternary pump, on-line vacuum degasser, and thermostatic column compartment, connected in line to a mass spectrometer. $20 \mu \mathrm{l}$ of the sample was prepared and injected into the HPLC system using LiChroCART RP-18e column $(150 \times 4.6 \mathrm{~mm}, 5 \mu \mathrm{m})$. Acetonitrile (solvent A) and $10 \mathrm{mM}$ ammonium formate buffer $\mathrm{pH}$ 4 with formic acid (solvent B) were used as mobile phase. The column was first equilibrated with $100 \%$ solvent B for $5 \mathrm{~min}$ and thereafter the ratio of solvent A was increased to $40 \%$ in 60 min 
with flow rate of $1.0 \mathrm{ml} / \mathrm{min}$ and column temperature was controlled at $40^{\circ} \mathrm{C}$. The mass spectrometer was fitted to an atmospheric pressure electrospray ionization (ESI) source, operated in positive ion mode. The electrospray capillary voltage was set to $4000 \mathrm{~V}$, with a nebulizing gas flow rate at $13 \mathrm{~L} / \mathrm{min}$ and a drying gas temperature of $320^{\circ} \mathrm{C}$. Mass spectrometry data were acquired in the scan mode (mass range $\mathrm{m} / \mathrm{z}$ 100-700). Phenolic standards consisted of caffeic acid, rosmarinic acid and hydroquinone while, flavonoids were catechin, rutin, isoquercetin, eriodictyol, quercetin, apigenin and kaempferol.

\section{Cell culture}

Murine macrophage RAW264.7 cells obtained from the American Type Culture Collection (ATCC, USA) were grown and maintained in in RPMI-1640 medium supplemented with 10\% fetal bovine serum and $1 \%$ penicillin-streptomycin and incubated in culture flasks at $37^{\circ} \mathrm{C}$ in a humidified atmosphere of $5 \% \mathrm{CO}_{2}$ and $95 \%$ air in a cabinet incubator. The cells were harvested with $0.25 \%$ trypsin-EDTA and suspended in a fresh medium. Cells were counted by a standard trypan blue cell-counting technique [23].

\section{Determination of MT toxicity in RAW264.7 macrophage cells}

Cytotoxicity of methomyl (MT) was investigated to determine the concentration causing $50 \%$ cytotoxicity $\left(\mathrm{CC}_{50}\right)$ by using the MTT assay after the modified method of Mosmann [24]. Briefly, cells were plated in a 96-well plate at a density of $1 \times 10^{6}$ cells $/ \mathrm{ml}$ and allowed to attach for $2 \mathrm{~h}$ before being tested with the MT at various concentrations $(100-600 \mu \mathrm{g} / \mathrm{ml})$ for $24 \mathrm{~h} .100 \mu \mathrm{l}$ of MTT $(0.5 \mathrm{mg} / \mathrm{ml})$ was added to each well and incubated for $2 \mathrm{~h}$ at $37^{\circ} \mathrm{C}$. After incubation, the media were aspirated and $100 \mu \mathrm{l}$ of DMSO was added to each well to dissolve the formazan for $10 \mathrm{~min}$ at $37^{\circ} \mathrm{C}$ before taking readings at $570 \mathrm{~nm}$ with a microplate spectrophotometer. The percentage viability reduction of the population was calculated as follows;

$$
\begin{aligned}
& \% \text { Cell viability }=[\text { ODs } / \text { ODc }] \times 100 \\
& \text { Where } S=\text { Sample }(\mathrm{MT}) \\
& \mathrm{C}=\text { Control }
\end{aligned}
$$

The $\mathrm{CC}_{50}$ for MT was calculated by plotting the percentage viability versus the concentrations of MT.

\section{Determination of the effects of CDE on RAW264.7 macrophage cells treated with MT}

The effect of the plant extract on RAW 264.7 cells treated with MT at $\mathrm{CC}_{50}$ was investigated. Briefly, cells were plated in a 96-well plate at a density of $1 \times 10^{6}$ cells $/ \mathrm{ml}$ and allowed to attach to the culture plate for $2 \mathrm{~h}$ before used in the experiments. Atropine sulfate (AS) was used as a positive control. Three treatment regimes were used in which the cells were either concurrently incubated with CDE solution or AS for $24 \mathrm{~h}$, pre-incubated with CDE solution or AS for $24 \mathrm{~h}$ before being aspirated and then treated with $\mathrm{MT}\left(\mathrm{CC}_{50}\right)$, or treated with $\mathrm{MT}\left(\mathrm{CC}_{50}\right)$ for $24 \mathrm{~h}$ before being aspirated and then treated with $\mathrm{CDE}$ solution or AS for a further $24 \mathrm{~h}$. In these experiments, the extract has contact with the cells for $24 \mathrm{~h}$ before, after or together with MT as follows: 
Group 1 (Combined-treatment, added the extract and $\mathrm{MT}\left(\mathrm{CC}_{50}\right)$ together)

- Normal control

: Media (24 h)

- Negative control

: Media and MT at $\mathrm{CC}_{50}(24 \mathrm{~h})$

- Positive control

: AS and MT at $\mathrm{CC}_{50}(24 \mathrm{~h})$

- Tasted sample

: Extract and MT at $\mathrm{CC}_{50}(24 \mathrm{~h})$

Group 2 (Pre-treatment, added extract before MT $\left(\mathrm{CC}_{50}\right)$ )

- Normal control

: Media (24 h) + Media (24 h)

- Negative control

: Media $(24 \mathrm{~h})+$ MT at $\mathrm{CC}_{50}(24 \mathrm{~h})$

- Positive control

: AS $(24 \mathrm{~h})+\mathrm{MT}$ at $\mathrm{CC}_{50}(24 \mathrm{~h})$

- Tasted sample

: Extract $(24 \mathrm{~h})+\mathrm{MT}$ at $\mathrm{CC}_{50}(24 \mathrm{~h})$

Group 3 (Post-treatment, added extract after toxin $\left(\mathrm{CC}_{50}\right)$ )

- Normal control

: Media (24 h) + Media (24 h)

- Negative control

: MT at $\mathrm{CC}_{50}(24 \mathrm{~h})+$ Media $(24 \mathrm{~h})$

- Positive control

: MT at $\mathrm{CC}_{50}(24 \mathrm{~h})+\mathrm{AS}(24 \mathrm{~h})$

- Tasted sample

: MT at $\mathrm{CC}_{50}(24 \mathrm{~h})+$ Extract $(24 \mathrm{~h})$

The amount of cell viability was detected by MTT cytotoxicity assay and calculated percentage of cell viability as followed equation;

$\%$ Cell viability $=[$ ODs $/$ ODc $] \times 100$

Where $\mathrm{S}=$ Negative control/Positive control/Tasted sample

$\mathrm{C}=$ Normal control

\section{Statistical analysis}

Data were subjected to analysis of variance (ANOVA). Comparison of means was carried out by Duncan's multiple range tests. Significance was declared at $p<0.05$ using the statistical software.

\section{RESULTS AND DISCUSSION}

\section{Total extractable phenolic and flavonoid contents and antioxidant activity}

Leaves of T. laurifolia have been used to prepare a tea and Thai folk medicines for centuries with therapeutic applications due to antioxidant properties. In the experiments reported here, TPC, TFC contents and the antioxidant activity of the extract were determined as ABTS, DPPH, FRAP and ferrous ions chelating activity (FIC) and the results are presented in Table 1 . The results showed that a higher value of TPC in this experiment as $623 \pm 6 \mu \mathrm{mol} \mathrm{GAE} / \mathrm{g} \mathrm{CDE}(106 \pm 1 \mathrm{mg} / \mathrm{g} \mathrm{CDE})$ was found compared with other previously published data. Thus, Oonsivilai et al. [25] reported that TPC in aqueous leaf extract of $T$. laurifolia was $24.33 \pm 0.57 \mathrm{mg} \mathrm{GAE} / \mathrm{g}$ extract while, Pukumpuang et al. [26] reported as $22.18 \pm 1.269 \mathrm{mg} \mathrm{GAE} / \mathrm{g}$ extract. The difference of TPC and TFC contents including the antioxidant activity may depend on many variable factors such as planting location, extract preparation and stage of leaf development $[8,12,26]$. In the experiments reported here, developing leaves of $T$. laurifolia were extracted with boiling water as a high polarity solvent Chan et al. [27] reported that the developing leaves of T. laurifolia had the highest TPC compared with young and mature leaves. Moreover, Oonsivilai et al. [25] reported that the sample extracted with water showed the highest of TPC followed by ethanol and acetone extractions, respectively, while Wonkchalee et al. [13] reported that using boiled water for extraction of dried $T$. laurifolia leaves gave the highest FRAP assay values compared with using water at room temperature with both fresh and dried leaf extraction. In this study, the results 
showed that antioxidant activity was highest in DPPH assay followed by the FRAP and ABTS tests, respectively. It is well known that DPPH assay responds better to less polar antioxidants [28], which may be more efficiently extracted in these experiments than high polar antioxidant compounds Actually, using aqueous solvent should provide more high polarity antioxidant compounds which are easily determined by FRAP and/or ABTS assays [29]. Masek et al. [30] reported that caffeic acid, a member of the phenylpropanoid phenolic class, exhibited higher DPPH than ABTS activity. However, in this experiment high temperature water, dried powder and a leafdevelopment stage which normally contains less wax cuticle, were used for extraction. These conditions may destroy more heat sensitive and high polarity antioxidant compounds, leading to a higher proportion of lesser polarity, high heat resistant compounds instead. In addition, it was found that TFC and FIC, which can provide both primary and secondary antioxidant activity [31] found in the present work was high content of TFC with 4,181 $\pm 26 \mu \mathrm{mol}$ QE/g CDE and FIC with $6 \pm 1 \mu \mathrm{mol}$ EDTAE/g CDE, respectively. It seemed like TFC in the extract was higher than TPC even though it could not be directly concluded because of different methods and standard compounds used. Based on antioxidant activity and TPC, as well as TFC, it was confirmed that active compounds present in the extract were heat resistant and of medium polarity.

Table 1. Total extractable phenolic, flavonoid contents and antioxidant activity of T. laurifolia leaf aqueous extract

\begin{tabular}{ll}
\hline Activities & Extract \\
\hline Total phenolic and flavonoid contents & $623 \pm 6(\mu \mathrm{mol} \mathrm{GAE} / \mathrm{g} \mathrm{CDE})$ \\
TPC & $4,181 \pm 26(\mu \mathrm{mol} \mathrm{QE} / \mathrm{g} \mathrm{CDE})$ \\
TFC & \\
\hline Antioxidant activity & $993 \pm 14(\mu \mathrm{mol} \mathrm{TE} / \mathrm{g} \mathrm{CDE})$ \\
ABTS & $1,332 \pm 4(\mu \mathrm{mol} \mathrm{TE} / \mathrm{g} \mathrm{CDE})$ \\
DPPH & $1,122 \pm 32(\mu \mathrm{mol} \mathrm{TE} / \mathrm{g} \mathrm{CDE})$ \\
FRAP & $6 \pm 1(\mu \mathrm{mol} \mathrm{EDTAE} / \mathrm{g} \mathrm{CDE})$ \\
FIC &
\end{tabular}

TPC means total extractable phenolic content; TFC means total extractable flavonoid content; GAE means gallic acid equivalent; $Q E$ means quercetin equivalent; TE means Trolox equivalent; EDTAE means EDTA equivalent. Values are represent as mean \pm standard deviation $(n=3)$.

\section{Phenolic and flavonoid compounds determined by $L C$-MS}

The active compounds in the extract determined by HPLC reported from our previous study were pyrogallol, caffeic acid, rosmarinic acid and rutin [32]. While, constiuents of T. laurifolia extract from other scientific reports were gallic acid, caffeic acid, protocatechuic acid, chlorogenic acid, catechin, rutin, apigenin and rosmarinic acid when identify by HPLC and NMR [8, 33-37]. However, in the present work, LC-MS was used for characterization of phenolic and flavonoid compounds. Ten standard compounds, including 3 phenolics, such as caffeic acid, rosmarinic acid and hydroquinone and 7 flavonoids, such as catechin, rutin, isoquercetin, eriodictyol, quercetin, apigenin and kaempferol, were used (Table 2). The contents of caffeic acid, rutin, isoquercetin, rosmarinic acid, catechin, quercetin and apigenin were 199.21 $\pm 20.72,132.26 \pm 11.45,114.54 \pm 6.04$, $90.28 \pm 14.51,69.54 \pm 11.55,61.19 \pm 8.23$ and $41.32 \pm 4.16 \mathrm{mg} / \mathrm{kg} \mathrm{CDE}$, respectively. However, there was no pyrogallol as reported earlier. The results of this study showed the presence of caffeic acid, rutin and isoquercetin as the major compounds. Caffeic acid was reported as a strong antioxidant 
and responsible for different biological activities such as anti-inflammatory and anti-tumor $[38,39,40]$. While, rutin was reported to provide a stronger DPPH radical scavenging activity than butylated hydroxytoluene (BHT) and exhibited lipid peroxidation inhibition better than ascorbic acid at a concentration of $0.05 \mathrm{mg} / \mathrm{ml}$ [41]. However, there were some unknown of phenolic and flavonoid compounds in this experiment (Fig. 1) which may provide antioxidant activity and other biological activities, therefore further analysis still needs to be carried out.

Table 2. Phenolic and flavonoid contents of T. laurifolia leaf from aqueous extract determined by LC-MS

\begin{tabular}{lllccl}
\hline $\begin{array}{l}\text { Peak } \\
\text { NO. }\end{array}$ & Compounds & $\begin{array}{l}\text { Retention } \\
\text { time }(\mathbf{m i n})\end{array}$ & $\begin{array}{l}{[\mathbf{M}+\mathbf{H}]^{+}} \\
(\mathbf{m} / \mathbf{z})\end{array}$ & References & $\begin{array}{l}\text { Contents } \\
(\mathbf{m g} / \mathbf{k g ~ C D E})\end{array}$ \\
\hline 1 & Catechin & $12.54 \pm 0.02$ & 291.0 & {$[42,43,44]$} & $69.54 \pm 11.55$ \\
2 & Caffeic acid & $13.03 \pm 0.04$ & 181.1 & {$[43,45]$} & $199.21 \pm 20.72$ \\
3 & Rosmarinic acid & $14.67 \pm 0.27$ & 361.0 & {$[46]$} & $90.28 \pm 14.51$ \\
4 & Rutin & $5.34 \pm 0.01$ & 611.0 & {$[43,47,48]$} & $132.26 \pm 11.45$ \\
5 & Isoquercetin & $16.46 \pm 0.08$ & 465.0 & {$[49]$} & $114.54 \pm 6.04$ \\
6 & Hydroquinone & $23.80 \pm 0.28$ & 328.3 & {$[50]$} & $\mathrm{ND}$ \\
& & & & & \\
7 & Eriodictyol & $31.25 \pm 0.07$ & 289.0 & {$[44,51]$} & $\mathrm{ND}$ \\
8 & Quercetin & $34.16 \pm 0.28$ & 303.0 & {$[44,51]$} & $61.19 \pm 8.23$ \\
9 & Apigenin & $43.35 \pm 0.03$ & 271.0 & $44,49]$ & $41.32 \pm 4.16$ \\
10 & Kaempferol & $44.33 \pm 0.06$ & 287.0 & {$[42,44]$} & $\mathrm{ND}$ \\
\hline
\end{tabular}

$\mathrm{ND}=$ not detected; Values are represent as mean \pm standard deviation $(\mathrm{n}=3)$.

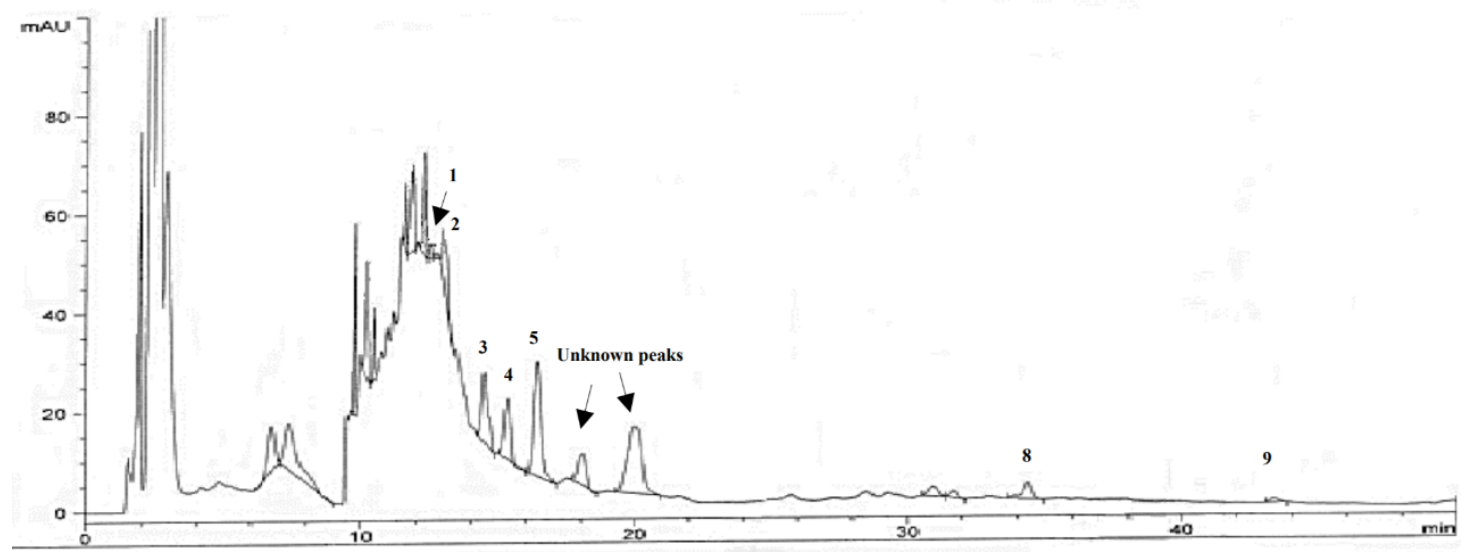

Figure 1. Chromatogram of phenolic and flavonoid compounds ${ }^{8}$. $\mathrm{n}$ T. laurifolic 9 aqueous leaf extract determined by LC-MS.

\section{Cytotoxicity of MT in RAW264.7 macrophage cells}

Methomyl (MT), a methyl carbamate insecticide, is reported to induce genotoxicity via chromosome aberrations, sister-chromatid exchanges and DNA damage and leads to the formation of micronuclei [52]. From the present work our results indicated that an increase of MT concentration led to a decrease in cell viability of RAW264.7 macrophage cells, with a strong - 
dependency correlation $\left(\mathrm{R}^{2}=0.9891\right)$. In addition, it was found the $\mathrm{CC}_{50}$ of MT was $545.57 \mu \mathrm{g} / \mathrm{ml}$ (Fig. 2) which was then selected as the working concentration for assessing the anti-MT activity of the extract sample.

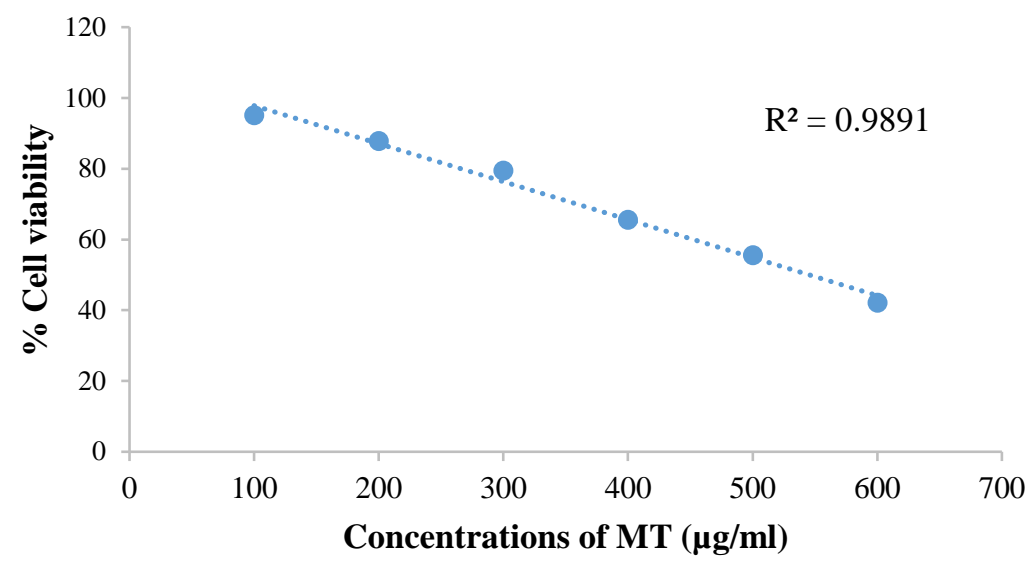

Figure 2. Effect of MT toxicity on cell viability determined by MTT assay

\section{Anti-MT activity of aqueous leaf extract from $T$. laurifolia in RAW264.7 macrophage cells}

The results of anti-MT activity of the extract are shown in Fig. 3. It was revealed that cell survival was increased when the extract and MT treatments were concurrent or when extract was added after MT treatment. However, no protective effect was observed after pre-treatment of RAW264.7 cells with extract followed by MT treatment. Thus, it may be that this folk medicine may have a curative or protective effect for farmers who have been exposed to MT but not for a prophylactic effect. However, generally, the standard drug atropine sulfate provided a greater protection of cell viability (Fig. A2, B2). Lertpongpipat et al. [53] reported that drinking Thunbergia tea could increase the level of cholinesterase, an enzyme located in the intercellular space that is responsible for acetylcholine degradation in the human nervous system. In fact, this important enzyme was inhibited by organophosphate and carbamate insecticides which effecting the degradation of acetylcholine and disbalancing the equilibrium leading to tetany. . Moreover, Chinacarawat et al. [54] suggested that oral administration of the T. laurifolia extract, at the dose of $600 \mathrm{mg}$ per day for 2 weeks, did not have any side effects in farmer volunteers who had a high risk of insecticide intake. However, in the in vitro studies we report here, the extract seemed not help and even at higher concentrations induced cell death in the pre-treatment group (Fig. 3B1). This may be due to the cytotoxicity of extract as an acute toxin induced more cell death. Moreover, cell viability clearly decreased when concentration of the extract exceeded $0.5 \mathrm{mg} / \mathrm{ml}$ in both the combined and post-treatment groups (Fig. 3A1 and 3C1). The morphology of cells that showed the highest cell viability in each of the treatments is shown in Fig 4. The changes of morphology of RAW 264.7 cells were found after adding extract alone or MT and the extract together. Cells shrank, had abnormal shapes and showed bubble-like protrusions when exposed to the extract alone, MT + extract or MT +atropine sulfate. This phenomenon is in agreement with the cytotoxicity activity of the extract that we reported in a previous study where we showed a dose-dependent reduction of cell viability when concentration of the extract increased [31]. The toxicity of the extract may be caused by phenolic and flavonoid compounds which have been reported under some circumstances to induce oxidative stress in cells $[55,56]$. Thus, possible pro-oxidant properties of phenolic and flavonoid compounds might be the cause of oxidative damage by reacting with various biomolecules, such as lipids, proteins and DNA, as has been reported elsewhere [57,58]. 
In fact, both phenolic and flavonoid compounds can have antioxidant and pro-oxidant properties depending on many factors including dose, structure of the particular polyphenol, cellular redox status or the presence of metal ions in system [58,59]. Moreover, some phenolic and flavonoid compound such as gallic acid and epigallocatechin gallate (EGCG) were reported to induce $\mathrm{H}_{2} \mathrm{O}_{2}$ generation, a cause of oxidative stress either intracellular and/or in cell culture medium and toxic to cells $[55,56]$. Some researchers reported that EGCG at a high concentration $(100 \mu \mathrm{M})$ could induce apoptosis in RAW264.7 macrophage cells by inhibiting autophagy, a lysosomal catabolic process that degrades accumulated and unnecessary intracellular materials $[59,60]$. While some flavonoids, such as apigenin, quercetin, naringenin, fisetin and myricetin, also induced apoptosis via pro-oxidant action, [61,62]. Furthermore, caffeic acid was reported to induce apoptosis via the mitochondrial apoptotic pathway [38]. These data emphasize that the type and concentration of phenolics and flavonoids can lead them to be viewed as 'good' or 'bad' substances in certain circumstances. Therefore, the results reported here suggest that caution should be exercised in in using $T$. laurifolia extract and that further studies are required, including those to identify which specific compounds exert anti-MT activity.

A2

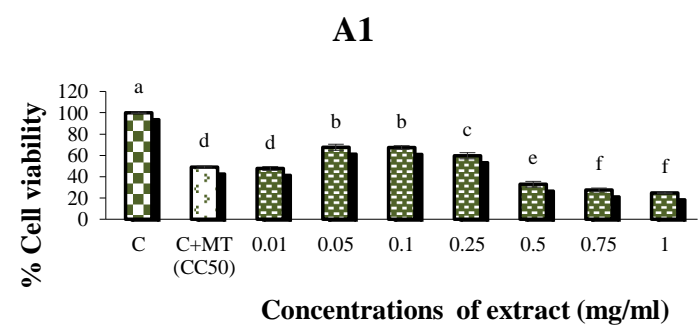

B1

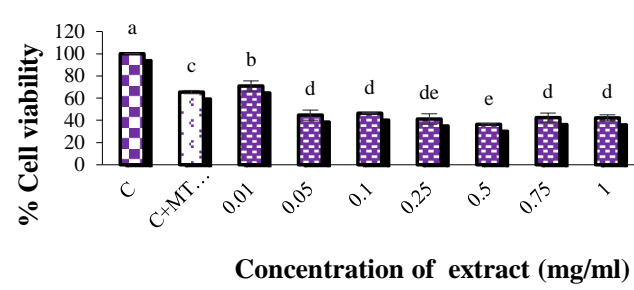

C2

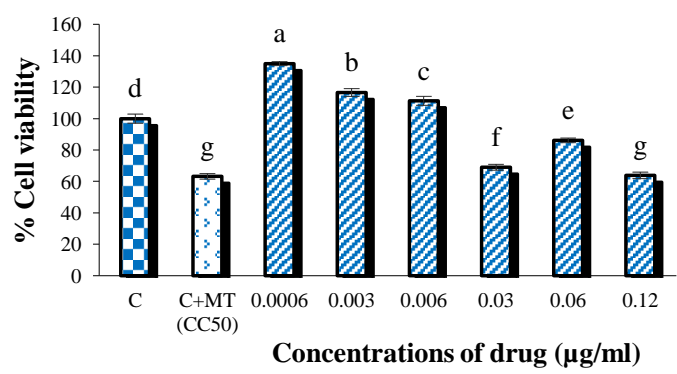

B2
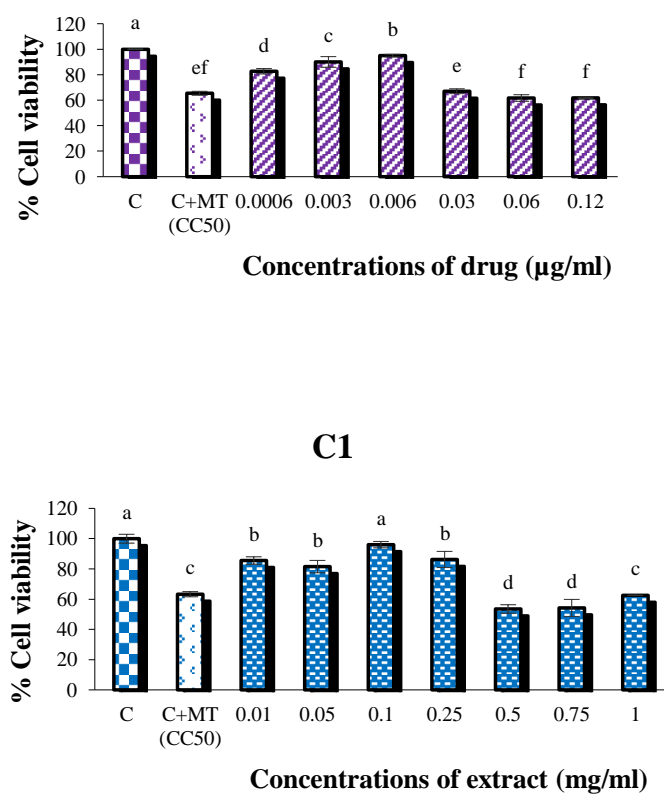

Figure 3. Anti-MT activity on RAW264.7 macrophage cells determined by MTT assay. A1 combined-treatment, B1 pre-treatment and $\mathrm{C} 1$ post-treatment with extract, and; A2 combined- 
treatment, B2 pre-treatment and C2 post-treatment with the standard drug atropine sulfate, respectively. ${ }^{\mathrm{a}-\mathrm{g}}$ mean different letters are significantly different $(p<0.05)$. Values are represented as mean \pm standard deviation $(n=3)$.

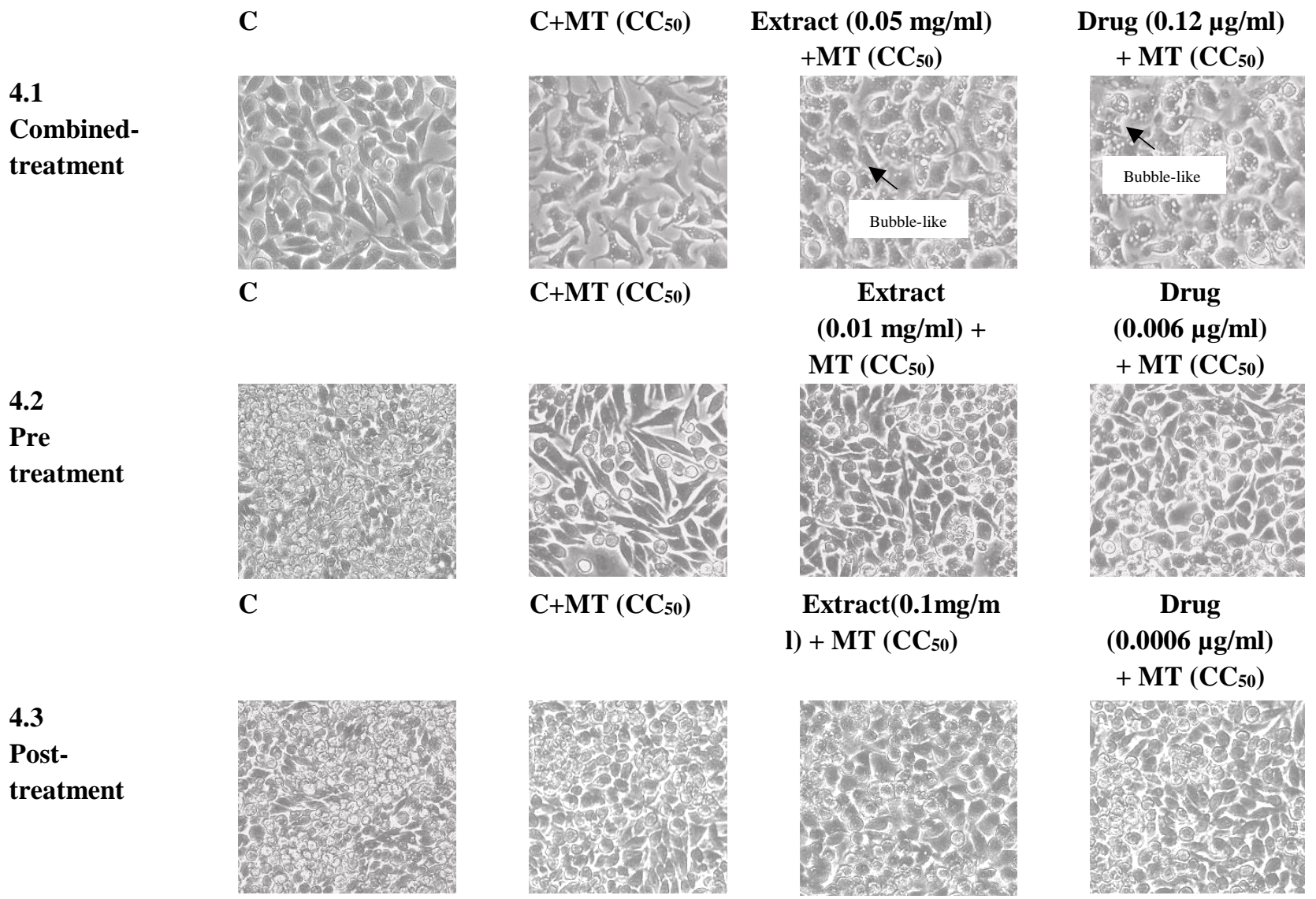

Figure 4. Morphology of RAW264.7 macrophage cells treated with extract, standard drug on MT toxin at various conditions. $\mathrm{C}$ mean normal control; $\mathrm{C}+\mathrm{MT}\left(\mathrm{CC}_{50}\right)$ mean negative control.

\section{CONCLUSION}

The aqueous leaf extract of T.laurifolia showed high of antioxidant activity based on TPC, TFC, ABTS, DPPH, FRAP and FIC. Phenolics, identified by LC-MS consisted of caffeic acid and rosmarinic acid, while flavonoid compounds were catechin, rutin, isoquercetin, quercetin and apigenin. The extract showed more effective healing rather than protective functions for anti-MT in RAW264.7 macrophage cells. Although the extract showed anti-dote function, further study is still needed.

List of Abbreviations: TPC, Total extractable phenolic content; MT, Methomyl; $\mathrm{CC}_{50}, 50 \%$ concentration of cytotoxicity; LC-MS, Liquid chromatography-mass spectrometry.

Competing Interests: All authors declare that they have no competing interests. 
Authors' Contributions: All authors contributed to this study work.

Acknowledgements and Funding: The authors would like to thank Prof. Dr. Alan Slusarenko (Plant Physiology Department, RWTH Aachen University, Germany) for kindly reviewing the English and the Graduate School PSU-Ph.D. Scholarship, Graduate School Dissertation Funding for Thesis, Overseas Thesis Research Scholarship from Prince of Songkla University for the financial support.

\section{REFERENCES}

1. Grovermann C, Schreinemachers P, Berger T: Quantifying pesticide overuse from farmer and societal points of view: an application to Thailand. Crop Prot 2013, 53:161168.

2. Panuwet P, Siriwong W, Prapamontol T, Ryan PB, Fiedler N, Robson MG, Barr DB: Agricultural pesticide management in Thailand: status and population health risk. Environ Sci Policy 2012, 17:72-81.

3. Sapbamrer R, Damrongsat A, Kongtan P: Health impact assessment of pesticide use in northern Thai farmers. J Environ Res 2011, 33:1-11.

4. Tamimi M, Qourzal S, Assabbane A, Chovelon JM, Ferronato C, Emmelin C, Ait-Ichou Y: Photocatalytic degradation of pesticide methomyl determination of the reaction pathway and identification of intermediate products. Photochem Photobiol Sci 2009, 5:477-482.

5. Amritha GK, Kaliwal BB: Effect of methomyl on protease activity in Pseudomonas aeruginosa. AJST 2016, 7:3358-3361.

6. Morkmek N, Chattaviriya P, Lertprasertsuke N, Chuncharunee S, Ruangyuttikarn W: Detoxification of cadmium induced renal and hepatic injuries in rats by Thunbergia laurifolia Lindl. leaf extract. Thai J Toxicology 2010, 25:115-123.

7. Thongsaard W, Marsden CA: A herbal medicine used in the treatment of addiction mimics the action of amphetamine on in vitro rat striatal dopamine release. Neurosci Lett 2002, 329:129-132.

8. Oonsivilai R: Functional and nutraceutical properties of Rang Chuet (Thunbergia laurifolia Lindl.) extracts. PhD Thesis. Suranaree University of Technology, Food Technology; 2006.

9. Inta $\mathrm{A}$, Trisonthi $\mathrm{P}$, Trisonthi $\mathrm{C}$ : Analysis of traditional knowledge in medicinal plants used by Yuan in Thailand. J Ethnopharmacol 2013, 149:344-351.

10. Rocejanasaroj A, Tencomnao T, Sangkitikomol W: Thunbergia laurifolia extract minimizes the adverse effects of toxicants by regulating P-glycoprotein activity, CYP450, and lipid metabolism gene expression in HepG2 cells. Genet Mol Res 2014, 13:205-219.

11. Maneenoon K, Khuniad C, Teanuan Y, Saedan N, Prom-in S, Rukleng N, Kongpool W, Pinsook, P, Wongwiwat W: Ethnomedicinal plants used by traditional healers in Phatthalung province, peninsular Thailand. J Ethnobiol Ethnomed 2015, 11:1-20. 
12. Chan EWC, Eng SY, Tan YP, Wong ZC, Lye PY, Tan LN: Antioxidant and sensory properties of Thai herbal teas with emphasis on Thunbergia laurifolia Lindl. Chiang Mai J Sci 2012, 39:599-609.

13. Wonkchalee O, Boonmars T, Aromdee C, Laummaunwai P, Khunkitti W, Vaeteewoottacharn, K, Sriraj P, Aukkanimart R, Loilome W, Chamgramol Y, Pairojkul $\mathrm{C}, \mathrm{Wu} \mathrm{Z}$, Juasook A, Sudsarn P: Anti-inflammatory, antioxidant and hepatoprotective effects of Thunbergia laurifolia Linn. On experimental opisthorchiasis. Parasitol Res 2012, 111:353-359.

14. Guideline and checklist for food license request [http://food.fda.moph.go.th/data/manual/2(10)_Re-Process.pdf]

15. Thailand Food and Drug Administration [http://region4.prd.go.th/ewt_news.php?nid=68660]

16. Ruangyuttikarn W, Chattaviriya P, Morkmek N, Chuncharunee S, Lertprasertsuke N: Thunbergia laurifolia leaf extract mitigates cadmium toxicity in rats. Sci Asia 2013, 39:19-25.

17. Tan KW, Kassim MJ: A correlation study on the phenolic profiles and corrosion inhibition properties of mangrove tannins (Rhizophora apiculata) as affected by extraction solvents. Corros Sci 2011, 53:569-574.

18. Yang H, Dong Y, Du H, Shi H, Peng Y, Li X: Antioxidant compounds from propolis collected in Anhui, China. Molecules 2011, 16:3444-3455.

19. Arnao MB, Cano A, Acosta M: The hydrophilic and lipophilic contribution to total antioxidant activity. Food Chem 2001, 73:239-244.

20. Shimada K, Fujikawa K, Yahara K, Nakamura T: Antioxidative properties of xanthan on the antioxidation of soybean oil in cyclodextrin emulsion. J of Agr Food Chem 1992, 40:945-948.

21. Benzie IF, Strain JJ: The ferric reducing ability of plasma (FRAP) as a measure of "antioxidant power": the FRAP assay. Anal Biochem 1996, 239:70-76.

22. Decker EA, Welch B: Role of ferritin as a lipid oxidation catalyst in muscle food. J Agr Food Chem 1990, 38:674-677.

23. $\quad \mathrm{ATCC}^{\circledast}$ animal cell culture guide, tips and techniques for continuous cell lines. [https://www.atcc.org/ /media/PDFs/Culture\%20Guides/AnimCellCulture_Guide.ash $\mathrm{x}]$

24. Mosmann T: Rapid colorimetric assay for cellular growth and survival: application to proliferation and cytotoxic assays. J Immunol Met 1983, 65:55-63.

25. Oonsivilai R, Ferruzzi MG, Ningsanond S: Antioxidant activity and cytotoxicity of Rang Chuet (Thunbergia laurifolia Lindl.) extracts. As J Food Ag-Ind 2008, 1:116-128.

26. Pukumpuang W, Thongwai N, Tragoolpua Y: Total phenolic contents, antibacterial and antioxidant activities of some Thai medicinal plant extracts. J Med Plants Res 2012, 6:4953-4960. 
27. Chan EWC, Lye PY, Eng SY, Tan YP: Antioxidant properties of herbs with enhancement effects of drying treatments: a synopsis. Free Radicals and Antioxidants 2013, 3:2-6.

28. Berker KI, Olgun FAO, Ozyurt D, Demirata B, Apak R: Modified folin-ciocalteu antioxidant capacity assay for measuring lipophilic antioxidants. J Agric Food Chem 2013, 61:4783-4791.

29. Martysiak-Żurowska D, Wenta W: A comparison of ABTS and DPPH methods for assessing the total antioxidant capacity of human milk. Acta Sci Pol Technol Aliment 2012, 11:83-89.

30. Masek A, Chrzescijanska E, Latos M: Determination of antioxidant activity of caffeic acid and p-coumaric acid by using electrochemical and spectrophotometric assays. Int $\mathrm{J}$ Electrochem Sci 2016, 11:10644-10658.

31. Lim YY, Lim TT, Tee JJ: Antioxidant properties of several tropical fruits: a comparative study. Food Chem 2007, 103:1003-1008.

32. Junsi M, Siripongvutikorn S, Takahashi Yupanqui C, Usawakesmanee W: Efficacy of Thunbergia laurifolia (Rang Jued) aqueous leaf extract for specific biological activities using RAW 264.7 macrophage cells as test model. Int Food Res J 2017, in press.

33. Kanchanapoom T, Kasai R, Yamasaki K: Iridoid glucosides from Thunbergia laurifolia. Phytochemistry 2002, 60:769-771.

34. Mahasaraku K, Sakkayawong N, Na Nakorn P: Shelf-life of herbal beverage from Thunbergia laurifolia Lindl. in bottles: chemical and physical properties and antioxidant activities. Thai J Sci Tech 2013, 2:140-152.

35. Boonyarikpunchai W, Sukrong S, Towiwat P: Antinociceptive and anti-inflammatory effects of rosmarinic acid isolated from Thunbergia laurifolia Lindl. Pharmacol Biochem Behav 2014, 124:67-73.

36. Suwanchaikasem P, Chaichantipyuth C, Sukrong S: Antioxidant-guided isolation of rosmarinic acid, a major constituent from Thunbergia laurifolia, and its use as a bioactive marker for standardization. Chiang Mai J Sci 2014, 41:117-127.

37. Sultana KW, Chatterjee S, Roy A, Chandra I: Review: An overview on ethnopharmacological and phytochemical properties of Thunbergia sp. Med. Aromat Plants 2015, 4:1-6.

38. Chang W, Hsieh C, Hsiao M, Lin W, Hung Y, Ye J: Caffeic acid induces apoptosis in human cervical cancer cells through the mitochondrial pathway. Taiwan J Obstet Gynecol 2010, 49:419-424.

39. Chao C, Mong M, Chan K, Yin M: Anti-glycative and anti-inflammatory effects of caffeic acid and ellagic acid in kidney of diabetic mice. Mol Nutr Food Res 2010, 54:388-395.

40. Sato Y, Itagaki S, Kurokawa T, Ogura J, Kobayashi M, Hirano T, Sugawara M, Iseki K: In vitro and in vivo antioxidant properties of chlorogenic acid and caffeic acid. Int $\mathrm{J}$ Pharm 2011, 403:136-138. 
41. Yang J, Guo J, Yuan J: In vitro antioxidant properties of rutin. LWT-Food Sci Technol 2008, 41:1060-1066.

42. Vihakas M: Flavonoids and other phenolic compounds: characterization and interactions with lepidopteran and sawfly larvae. PhD Thesis. University of Turku, Department of Chemistry; 2014.

43. Sun J, Liang F, Bin Y, Li P, Duan C: Screening non-colored phenolics in red wines using liquid chromatography/ultraviolet and mass spectrometry/mass spectrometry libraries. Molecules 2007, 12:679-693.

44. Tsimogiannis D, Samiotaki M, Panayotou, G, Oreopoulou V: Characterization of flavonoid subgroups and hydroxy substitution by HPLC-MS/MS. Molecules 2007, 12:593-606.

45. Falcão SI, Vale N, Gomes P, Domingues MRM, Freire C, Cardoso SM, Vilas-Boas M: Phenolic profiling of Portuguese propolis by LC-MS spectrometry: uncommon propolis rich in flavonoid glycosides. Phytochem Anal 2013, 24:309-318.

46. Mena P, Cirlini M, Tassotti M, Herrlinger KA, Asta CD, Rio DD: Phytochemical profiling of flavonoids, phenolic acids, terpenoids, and volatile fraction of a rosemary (Rosmarinus officinalis L.) extract. Molecules 2016, 21:1-15.

47. Bravo L, Goya L, Lecumberri E: LC/MS characterization of phenolic constituents of mate (Ilex paraguariensis, St. Hil.) and its antioxidant activity compared to commonly consumed beverages. Food Res Int 2007, 40:393-405.

48. Bino RJ, Vos RD, Lieberman M, Hall RD, Bovy A, Jonker HH, Tikunov Y, Lommen A, Moco S, Levin I: The light-hyperresponsive high pigment- $2^{d g}$ mutation of tomato: alterations in the fruit metabolome. New Phytol 2005, 166:427-438.

49. Simirgiotis MJ: Antioxidant capacity and HPLC-DAD-MS profiling of Chilean Peumo (Cryptocarya alba) fruits and comparison with German Peumo (Crataegus monogyna) from southern chile. Molecules 2013, 18:2061-2080.

50. Almodóvar I, Ramírez-Rodríguez O, Barriga A, Rezende MC, Araya-Maturana R. Electrospray ionization mass spectrometric fragmentation of hydroquinone derivatives. Rapid Commun Mass Spectrom 2011, 25:370-378.

51. Fabre N, Rustan I, Hoffmann ED, Quetin-Leclercq J: Determination of flavone, flavonol, and flavanone aglycones by negative ion liquid chromatography electrospray ion trap mass spectrometry. J Am Soc Mass Spectrom 2001, 12:707-715.

52. Guanggang X, Diqiu L, Jianzhong Y, Jingmin, G, Huifeng, Z, Mingan S, Liming T: Carbamate insecticide methomyl confers cytotoxicity through DNA damage induction. Food Chem Toxicol 2013, 53: 352-358.

53. Lertpongpipat W, Chaiyakhun D: Comparison of effectiveness on increasing cholinesterase blood level between Thunbergiaceae and Bauhinia strychnifolia craib in agriculturists. J of the office of DPC 6 Khon Kaen 2011, 18:49-58.

54. Chinacarawat N, Kiettinun S, Amatayakul C, Jaiaree N, Itharat A, Chinsoi P: Study on the efficacy and side effects of Thunbergia laurifolia Lindl. extract on reducing 
chemical toxicity among agricultural workers receiving organophosphate and carbamate insecticide poisoning (clinical trial phase II). Thammasat Med J 2012, 12:496-505.

55. Halliwell, B: Review: Are polyphenols antioxidants or pro-oxidants? What do we learn from cell culture and in vivo studies?. Arch Biochem Biophys 2008, 476:107-112.

56. Halliwell B: Review: Cell culture, oxidative stress, and antioxidants: avoiding pitfalls. Biomed J 2014, 37:99-105.

57. Procházková $\mathrm{D}$, Boušová I, Wilhelmová N: Review: Antioxidant and prooxidant properties of flavonoids. Fitoterapia 2011, 82:513-523.

58. Yordi EG, Pérez EM, Matos MJ, Villares EU. Antioxidant and Pro-Oxidant Effects of Polyphenolic Compounds and Structure-Activity Relationship Evidence. In Origins of Nutrition, Well-Being and Health. Edited by Bouayed J. Croatia: InTech; 2012:23-48.

59. Kim H-S, Quon MJ, Kim J-A: Mini review: New insights into the mechanisms of polyphenols beyond antioxidant properties; lessons from the green tea polyphenol, epigallocatechin 3-gallate. Redox Biol 2014, 2:187-195.

60. Hashimoto K, Sakagami H: Induction of apoptosis by epigallocatechin gallate and autophagy inhibitors in a mouse macrophage-like cell line. Anticancer Res 2008, 28:1713-1718.

61. Galati G, O’Brien PJ: Potential toxicity of flavonoids and other dietary phenolics: significance for their chemopreventive and anticancer properties. Free Radic Biol Med 2004, 37:287-303.

62. Kyselova Z: Review: Oxicological aspects of the use of phenolic compounds in disease prevention. Interdiscip Toxicol 2011, 4:173-183. 